\title{
Deteriorating Performance of Students of Community School in English
}

\author{
Parmeshor Baral \\ Prithvi Narayan Campus, Pokhara
}

\begin{abstract}
Tremendous attempts have been made to ensure the quality of education and educational status of the students since if performance in the English language is good, it opens the door of the vast ocean of knowledge. Even though community school education in Nepal receives a significant portion of the total national budget, students' performance in those schools is below average, when compared to students in private institutions with limited resources and teachers who receive merger remuneration. This paper attempts to shed light on the causes of poor performance in the English language among Nepalese community school students in Nepal. This is a qualitative study in which assertions are backed up by pieces of evidence. It is based on previous studies about deteriorating English language performance in the world in general, and in Nepal in particular. The study identified student enrolment, motivation and language learning, politicization, lack of teachers' professional development, and limited exposure to the English language as the major causes of students' poor performance in English.
\end{abstract}

Keywords: poor performance, English language, causes, community schools.

\section{INTRODUCTION}

The Government's initiative in education is very important and the Constitution of Nepal (2015) provisioned education up to the secondary level free of cost in all community schools throughout the nation (Ministry of Education, 2015). For example, education accounts for nearly 18 percent of the country's total budget, with community school education accounting for more than 80 percent of that (Ministry of Education, 2015). Even if such a huge amount of the financial contribution is there from the end of the government in community schools, those schools are criticized for not delivering high-quality education for a variety of reasons as end examination results of those schools is very frustrating and below-average comparing the result with privately owned schools (Timsina, 2008). Moreover, $80 \%$ of total enrolled students study in those community schools, however, the final examination (SLC) performance of the students of those community schools is unsatisfactory and students are not entirely to blame (Thapa, 2013). Moreover, School Sector Reform Project (2009) asserted that the average achievement of the students has consistently been remained below 50\%, implying that they have accomplished less than half of what their curriculum requires in community schools.

Education is to be practical in this $21^{\text {st }}$ century and practical education ensures smooth learning. The importance of the English language can hardly be exaggerated in countries like Nepal because it is regarded as a master-key that opens the doors of a vast pool of knowledge. It is because competency in English yields opportunities to study any course one wants to pursue in world education for a skillful learner. Because of a good command of the English language, 
hundreds of thousands of Nepali students go to developed countries to continue their further studies. It is one of the requirements for admission to those countries is the demonstration of their competency in the English language and from this fact it can be easily understood the importance of the English language in the world of education in general and in developing countries like Nepal in particular. Even if learning the English language has been given much more priority, performance in community schools in Nepal in the English language has not been found satisfactory, and the statistics show that the results are frustrating (Mathema, 2007). In Nepal, there is a tendency that whenever a student has bad performance blame is given to teachers but contrary to this if the student performs better, the attribution is given to the respective students. This mindset of stakeholders, especially that of parents is dangerous because it demotivates teachers causing them to stop working as hard as they once did (Parajuli \& Das, 2013). In reality, several factors contribute to the poor performance of students in community schools in Nepal and some of these comprise of lack of qualified teachers, the politicization of each issue, lack of exposure to the content to be taught and learned, and considering and studying the English language as a subject (Kandel, 2014). Not only that, but there must be some gap between the policy, implementation, and output of teaching and learning of English in community schools in Nepal.

\section{LITERATURE REVIEW}

Many studies have been conducted around the world to find out the possible causes of poor English language performance in community schools. For example, Hashemi (2011) pointed out that students' weakness in English language learning in Laos was due to the difference in social contexts, cultural environments, i.e., in the environments where the first and second language learning takes place. The case of Nepali secondary schools is also the same in the sense that the socio-cultural environments for learning are not conducive for the English language since most of the classroom discourses are carried out in the Nepali language. Later on, Musa, Lie, and Azman (2012) in Malaysia identified different causes for poor performance in English by community school students that included students' perception towards English as a difficult subject to learn, over dependency on teachers, lack of support from home and community, limited exposure, unwillingness to use English for a communicative purpose, and lack of motivation to learn. In the subsequent year, Saad, Adamu, and Sadiq (2014) found that the poor performance in community schools in Nigeria comprised dominance of mother tongue, inadequately trained teachers, lack of facilities and instructional materials, students' negative attitude towards learning English, and teachers' improper use of methods of teaching English.

Similarly, Parajuli and Das (2013) in their study investigated three causes of poor performance in the English language in Nepal. The first issue was physical and structural that comprised of having poor school building, inappropriate textbooks, inadequate teaching materials, the geographical location of schools; the second was quality issues comprising of untrained and unresponsive teachers, impractical curriculum, less reflection of training into the classroom; and the third was non-educational issues like poverty and social exclusion as the inhibitors for the poor performance of students in the English language in Nepali community schools. Earlier, Bista (2011) reported that the English language has not received the same status 
in public schools like that of private schools in Nepal because of its limited use which impeded students' poor performance in the national level examination. The reasons he pointed out for poor performance in the English language comprised a lack of trained teachers, improved textbooks, enough supplementary materials, mother tongue dominance, and not having a better evaluation system. Finally, Kandel (2014) found the causes for poor performance in English encompassed the gap between theory and practice of English language teaching, overcrowded classes, poor physical facilities, overdependence on teachers, treating English as a subject rather than a language, government's policy, phobia towards learning English and less exposure. However, this study particularly focuses on the causes of poor performance in the English language by the students of community schools of Nepal sharing the frame of references of the previous studies to illuminate the root cause for such a deteriorating performance so that concerned stakeholders can strategize their teaching and learning practices in the days to come.

\section{METHODOLOGY}

To explore the deteriorating performance of students in the community schools of Nepal, the study posed the research question as "what are the underlying causes behind the poor performance of students in the English language in community colleges in Nepal?"As the objective of this paper is to explore the causes of secondary level students' poor performance in English in Nepal, the study used a qualitative method so it collected the evidence of poor performances of the students from different sources. It is because using the qualitative method; I could be able to dig deep so that valid and verifiable pieces of evidence could be brought sharing the frame of references of previously published works (Denzin \& Lincoln, 2018; Creswell \& Creswell, 2018; Cohen, Manion \& Morrison, 2018). Those sources include different reports, journal articles, and conference proceedings. Using purposive non-random sampling procedure those pieces of evidence have been selected and while analyzing the data, sound arguments have been made so that justification of each theme could be made.

As mentioned above, the study depended on secondary data, and all the documents, reported and relevant literature related to the poor performance of students in the English language in Nepal has been collected. Following the framework of Braun and Clark (2006), the study first collected pieces of evidence of poor performance as mentioned above, formulated codes, and based on those codes, based on those themes were emerged, those themes were related with the fact that has been reported by different studies. Finally, the argumentation that is made in the topic sentence is related to the established literature. By doing so, a coherent argument can be developed for each theme. The thematic data analysis has been presented in the following section.

\section{RESULTS}

The English language has always been regarded as a difficult language for a variety of reasons (for example, there is no one-to-one correspondence between a sound and the letters it represents in the English language (Rao, 2018)), and learning English has always been a difficult task for Nepali students (Adhikari, 2010). The general causes of poor performance in the English language in the Nepali community schools' classroom can be listed as having a heterogeneous 
level of students, the large size of the classroom, not getting English specialized teachers in rural parts of the nation, the dominance of mother tongue, students' fear of providing wrong answers (Kandel, 2014; Parajuli \& Das, 2013). Moreover, the general tendency reported by many studies that many school supervisors do not go to those schools which are located in urban and geographically difficult to reach places, most of the teachers want to work in urban places and those teachers who are unable to be updated with the latest language teaching technologies should be made the provision of the golden handshake and should invite freshers from open competition. Even so, the study came up with the following themes about the poor performance of students in English in community schools in Nepal.

\section{Students' Enrolment}

The process involved in the production of something has to be genuine and if the characteristic of genuine can be maintained, the product can have an important resemblance of its genre in the pedagogical process. It is because whatever the raw materials (input, students in this context) one takes, the same is processed (teaching to those students) and output will have arrived (performance of the student). (What is the connection between the previous sentence and the following one?) In the same way, the students enrolled in community schools are mostly girls, ethnic minorities, and students from backward societies for whom learning the English language is just to pass the examination, and children from elite families prefer to choose private schools because they doubt on the quality of education provided by community schools (National Institute for Research and Training, 2017). Because of these reasons, the students enrolled in community schools do have satisfactory results. Mathema (2007) asserts that even after several years of schooling in English, most linguistic and ethnic minorities have difficulties in expressing themselves in the English language. It might have caused it because they consider learning English as merely a means of passing the exam rather than as a means of international communication. Mathema (2007) goes on to say that: Following the withdrawal by professionals, businessmen, government bureaucrats, university professors, and even school-teachers of their children, public schools in Nepal are now attended by girls and children from poor backgrounds and those living in difficult conditions. It is exactly for this reason that the problem of the massive failure of the SLC examination and the near-collapse of the public school system are ignored and not seen as a national problem (p. 64). Hence, special attention has to be paid while recruiting students as they are the flag carriers of an educational institution, and the success and failure of an institution are being determined by their performance and progress.

Moreover, Ghimire (2019) asserts that the quality of community schools' English language can be improved if all the government staff enroll their children in those schools. Besides, Shrestha (2008) argues that children from the aristocrat family receive English medium quality education that leads them to better career opportunities while the children from the middle class and lower middle class receive low-quality English medium education and are deprived of better career opportunities which have been impeding them to remain behind those the children of well-to-do families. This predicament is a contributing factor in the widening of social divides. Therefore, among many causes of poor performance in English, the types of students enrolled in community schools are the major variable behind poor performance on the part of students. 


\section{Motivation and Language Learning}

Aligned with the previous issue, the role of motivation is significant in English language learning since the English language is not spoken as a mother tongue in Nepal rather it is learned as a subject (Bista, 2011). If a learner is not well motivated, learning is beyond imagination in the sense that the learners' primary priority will be something different than learning the English language. The view of Kandel (2014) resonates it where he says in the communities where there is the problem of hand-to-mouth, the primary concern of children from those communities will be to manage food rather than to concentrate on the study. Most of the students from community schools are from the working class and before and after school they have to work to support their families. Therefore, their attention can be on something different than learning English in the classroom. In this connection, Ginsburg (1972) asserts that three factors are responsible for students' poor performance. They are bad teaching, motivation, and style...if students are motivated, there is interest and passion for learning. Contrary to this, students in most of the community schools have to focus on non-academic ventures, in such a perplexing context how we can imagine outstanding performance from such students in the English language.

Gardner and Moran (2006) assert that motivation is one of the factors that influence success or failure in learning a language, particularly when learning a foreign language or a second language. Likewise, according to Petty (1993), if students do not want to learn from their hearts, their learning efficiency will be inversely proportional. As a result, how can we expect a student from a community school to learn something from the heart when he or she is preoccupied with something other than learning English? Students in Nepal's English community schools performed poorly as a result of this fact this way too:

\section{Politicization}

Teachers are primarily responsible for the below-average performance of students in community schools because of their involvement in political activates than in academic activities (Ghimire, 2019; Pokhrel, 2020). Therefore, another factor for poor performance in English by the students of community schools in Nepal is politicization. It is widespread fact that community school teachers are affiliated with political parties and teachers' unions which gives them deference against possible action if they fail to perform their duty (Ghimire, 2019). Even if the Ministry of Education has formulated the provision of punishment to those teachers whose performance is very meager for three consecutive years (Ministry of Education, 2015), because of their involvement in political parties, no disciplinary actions are taken by the concerned authority. Moreover, schools are declared School as Zone of Peace (SZOP) by the Government of Nepal in 2011, schools have to refrain from any political interference but in reality, politics is deeply intruded into schools in such a way that in every action there is the interference of politics in school (Pokhrel, 2020). Those actions include the division of teachers into different political parties, debating for and against their political indoctrination during recesses, the appointment of the school management committee (SMC), and the teacher selection procedure. Can we imagine a quality education in the circumstance in which all the systems of community schools are fabricated by politics? The answer to this question is obviously "no". Therefore, the most important problem lies in politicization. 
On the other side, Mathema (2007) reiterates that if teachers refrain from politics, the quality of community schools can be improved; however, the problem is not local; rather, it is a national issue, and political leaders seem to have been patronizing teachers. If such practice is eliminated, the teachers may actively involve in the act of teaching. Therefore, I feel, teachers' involvement in politics is to be eradicated without any reservation. Moreover, if it is done teachers will be able to concentrate on classroom practices which will automatically add to improving students' performance.

\section{Teachers' Professional Development and other Factors}

Teachers' professional development is also another crucial variable for ensuring good performance on the part of students. It is believed that a qualified and trained teacher becomes able to impart education according to the need and levels of the students that $\mathrm{s} / \mathrm{he}$ teaching. If government reports are to be trusted, 96 percent of public school teachers are trained and they are paid according to rules and regulations of the Nepal government (Ghimire, 2019). If training and remuneration are satisfactory, there must be a connection of this issue with the issues raised above since the theory of human psychology asserts that a satisfied person performs an assigned job dutifully. Contrary to this, in private schools teachers rarely get an opportunity of attending training and get less salary (in most of the circumstances) but their students' performance is found outstanding is the most astonishing factor to be analyzed in the sense that why cannot students perform better by a well-trained and highly paid teacher in the community school. This issue is the most debatable issue which is frequently found in the public discourses with sharp dissatisfaction from academicians and other stakeholders and links this issue with previous ones.

Even if teacher training has been provided to all English language teachers throughout the nation, a report by Kerr (1994 as cited in Awasthi, 2010) asserts that... "the standard of written and spoken English amongst government (community)school teachers in Nepal ranges from Grade two to Grade four native speaker, with only a few exceptions" (p.11). After a thorough analysis, it seems that the real problem lies here. It is because English language teachers are not updated and do not study the latest theories, it might be the main issue of having a deteriorating condition of students in the English language. Additionally, the condition of the rural part of Nepal is the worst. For example, Mathema (2007) reports that:

The nationwide survey involving 450 secondary schools and approximately 22,500 students and the case studies of 28 effective and ineffective secondary schools carried out within the Study on Student SLC Performance reveals that hardly any teaching and learning take place in many public schools in rural areas. There are very little testing and no remedial support for students in difficulty. This practice of neglecting weak students starts at the primary level and carries on through secondary (p. 51).

Parajuli and Das (2013) advocate that most of the English teachers participated in different refresher training programs organized for effective teaching strategies by GOs, NGOs, and INGOs, but learned things are not transferred into the real classroom teaching due to negligence in one side and lack of strict monitoring and evaluation on the other. Another factor 
that is prevalent in community schools' English language classrooms is that teachers prefer to teach chalk and talk methods and do not dare to teach using the communicative method which is prevalent in all English language classrooms around the world (Awasthi, 2010). Therefore, it is important to change the methodology that teachers have been employing in teaching and they are to be updated with the latest language teaching approaches, methodologies, and approaches.

Another cause that Mathema (2007) points out was teachers' absenteeism. The most surprising factor is that even if teachers are present in the schools they do not teach because nobody can take action against them and the head-teachers are just onlookers for such serious offenses. This attitude is replicated by newcomers too. On the other hand, Mikesell (2006) points out that teachers' morale in most public schools is low for numerous reasons that comprised much politicizing, lack of professional support, ineffective and biased school management, inappropriate resources, and ineffective leadership.

\section{Exposure to the English Language}

In a typical community school in Nepal, the exposure to the English language is given just 45 minutes and the rest of the classroom teaching and learning activities are conducted in students' mother tongue. This is one of the factors for poor performance in English for the students of community schools in Nepal. When I went to some schools for data collection for my study, I found that teachers exclusively teaching in the Nepali language, and in this connection, Kerr (1999) as cited in (Awasthi, 2010)has presented an example of how the teaching and learning activities in English language classroom take place:

Teaching instruction consists of grammatical dissection and rote memorization of the text. This gives children no opportunity or encouragement to use the language. Further, the physical condition of the schools and large student numbers are not conducive to good teaching and learning. Teachers who can make additional teaching materials have no place to either store or display them ( $p$. 14).

Hence, the exposure to the English language needs to be accelerated since it is directly related to the performance of the students in the sense that the greater the exposure to the language, the greater will be the performance of the students which, in the Nepalese context, is lacking because of several reasons.

Similarly, students rarely get an opportunity to express their opinions in the English language as the study of Feldman (1989) projected the issue that ..."in Nepali community schools' classroom of English a student does not speak English for even ten minutes in ten years of studying the language" (p. 11). In such a condition how can we imagine good performance on the part of the student in the English language in those community schools as listening and speaking tests are taken only for showing without real-life implications.

\section{DISCUSSION}

Even if the government of Nepal has invested a large budget for community schools and enormous attempts for teachers' professional development, the outcome seems like pouring water 
on the sandy place. Because of several reasons the performance of secondary level students in general and in the English language, in particular, is very deteriorating while comparing it with the performance with students of private school (Mathema, 2007). The government and other stakeholders have done a tremendous effort to enhance the performance of community schools; all attempts have not been successful so far. Many studies, for example, Kandel (2014); Parajuli and Das (2013); (Bista, 2011) suggested having strict monitoring and supervision to all stakeholders to ensure the quality of teaching and learning English in those schools, such ideas seem to have remained unimplemented and the condition of English language is deteriorating day by day.

As it has been already advocated in the discussion above that learning the English language in community schools is not only a problematic issue in Nepal but a similar condition has been found in other countries too, for example, Saad et al. (2014) in Nigera, Musa et al. (2012) in Malaysia and Hashemi (2011) in Laos. In Nepal, the situation is a bit different than that of those on the ground that politicization has become one of the major issues that impede quality teaching and learning in Nepal. On the other hand, if all the government employees admit their children to the community schools, the quality of the English language can be improved. Moreover, in place of being the cadre of political parties, involved in political discussion during school time, if teachers sincerely concentrate on teaching and learning activities, the quality of the English language can be improved. Teachers who were trained should reflect whatever they have learned in classroom teaching while students should be motivated from all from home to school administration to learn English effectively showing the good consequences of learning English. Finally, the most problematic situation that has been found in English classrooms of community schools is less exposure to the English language. This should be immediately abandoned and English subjects should be taught using the English language.

\section{CONCLUSION}

The study explored different causes for the poor performance of students in the English language in community schools in Nepal and the problem is not only with the teaching and learning process as well as teachers and students. But the real problem lies in the policy that has been formulated by the administrative body. For example, the command over the English by a student in Kathmandu or Pokhara and with a student in Dolpa cannot be the same, but the same textbook is being imposed on them. On the other hand, the study found that the types of students enrolled in the community schools have less interest in learning since their primary purpose was to manage money for their hand to mouth. It is because those students who have been studying in community schools are mostly from the unprivileged and marginalized group and for them going to school and learning the English language was just to pass time. However, motivation and language learning on the part of those students were not good as such. Similarly, politicization was the most pressing problem that yielded deteriorating condition of students since neither teachers were found to be serious towards teaching nor students were serious towards the learning process. Finally, due to limited exposure to the English language, the poor performance of the students has been found. 


\section{REFERENCES}

Adhikari, B. R. (2010). Teaching speaking in the Nepalese context: Problems and ways of overcoming them. Journal of NELTA, 15(1-2), 1-9.

Awasthi. (2010). Teacher education with special reference to English language teaching in Nepal. Journal of NELTA, 8(1), 17-28.

Bista, K. (2011). An application of cooperative learning to teach English as a second/foreign language in Nepal. Education Resources Information Center, 11(32).

Braun, V., \& Clarke, V. (2019). Reflecting on reflexive thematic analysis. Qualitative Research in Sport, Exercise and Health, 11(4), 589-597.

Cohen, L., Manion, L., Morrison, K. (2018). Research methods in education. Routledge

Creswell, J.W., \& Creswell, J.D. (2018). Research design: qualitative, quantitative, and mixed methods approaches. Fifth edition. Sage.

Denzin, K, N \& Lincoln, Y.S. (2018). The Sage handbook of qualitative research. Sage.

Feldman, K. A. (1989). Instructional effectiveness of college teachers as judged by teachers themselves, current and former students, colleagues, administrators, and external (neutral) observers. Research in Higher Education, 30(2), 137-194.

Gardner, H., \& Moran, S. (2006). The science of multiple intelligences theory: A response to Lynn Waterhouse. Educational psychologist, 41(4), 227-232.

Ginsburg, H. (1972). The myth of the deprived child: Poor children's intellect and education.Education Resources Information Centre.

Hashemi, M. (2011). Language stress and anxiety among the English language learners. Procedia-Social and Behavioral Sciences, 30, 1811-1816.

Kandel, R. K. (2014). Resolving ELT challenges through critical thinking strategies. Journal of NELTA Surkhet, 4, 1-12.

Kerr, R. (1999). Planning and Practice: Factors impacting on the development of initial education in Nepal, with special reference to English language teaching, 1950-1995. Victoria University of Technology.

Mathema, K. B. (2007). Crisis in education and future challenges for Nepal. European Bulletin of Himalayan Research, 31, 46-66.

Mikesell, S. (2006). Thoughts on why the children of Nepal would join the revolution. People $\square s$ Power in Nepal, 53-58.

Ministry of Education . (2015). Nepal Education in Figures. Kathmandu: Government of Nepal

Musa, N. C., Lie, K. Y., \& Azman, H. (2012). Exploring English language learning and teaching in Malaysia. GEMA Online Journal of Language Studies, 12(1).

National Institute for Research and Training (2017). Nepal education sector analysis.

Kathmandu, Nepal.https://www.globalpartnership.org/sites/default/files/2019-05-nepaleducation-sector-analysis.pdf 
Parajuli, D. R., \& Das, T. (2013). Performance of community schools in Nepal: A macro level analysis. International Journal of Scientific and Technology Research, 2(7), 148-154.

Petty, G. (1993). Teaching today: A practical guide: Stanley Thornes Cheltenham.

Rao, V. C. (2018). English spelling and pronunciation: a brief study. J. Res. Sch. Profess. Eng. Lang. Teach, 2, 1-10.

Saad, T. U., Adamu, A., \& Sadiq, A. M. (2014). The causes of poor performance in mathematics among public senior secondary school students in Azare metropolis of Bauchi State, Nigeria. Journal of Research \& Method in Education, 4(6), 32.

Shrestha, S. (2018). English education in Nepal: A brief overview. Language Issues: The ESOL Journal, 29(1), 70-71.

Shrestha, P. (2008). ELT, ESP \& EAP in Nepal: Whose interests are served? In: Krzanowski, Mark ed. EAP and ESP in Developing Countries: State of Play vs Actual Needs and Wants. Canterbury: IATEFL (ESP SIG), 191-210.

School Sector Reform Plan. (2009). School Sector Development Plan Nepal FY 2016/172022/23 (BS 2073-2080) http://www.moe.gov.np/assets/uploads/files/MOE_SSDP_Final_Document_Oct_2016.pdf

Thapa, A. (2013). Does private school competition improve public school performance? The case of Nepal. International Journal of Educational Development, 33(4), 358-366.

Timsina, T. (2008). School effectiveness with preference to the public and private schools in Nepal: An unpublished M.phil Dissertation. Kathmandu University. 